\title{
Motif Analysis of Oscar Wilde's Fairy Tales
}

\author{
* Mehrish Khan, MPhil Scholar \\ ** Dr. Zahoor Hussain, Lecturer \\ *** Dr. Muhammad Ahsan, Lecturer (Corresponding Author)
}

\begin{abstract}
The study was aimed to do the motif analysis of Oscar Wilde's fairy tales as Wilde's fairy tales got significant weightage in his life and he in fact wrote the fairy tales for his sons. Wilde's fairy tales had almost the same tinge of imagination and supernatural atmosphere as found in the oral fairy tales and he exquisitely presented the sketch and plot of characters with a tug of war and finally like all other fairy tales meets the happy endings with some didactic lessons. The researchers used Thompson Motif Index as a theoretical framework and trace almost all types of motifs however the motifs of society were found most as compared to the other types of motifs. Through these motifs, he truly reflected the picture of his age and the current study also helped establish Wilde's fairy tales along with the oral tradition of fairy tales.
\end{abstract}

Keywords: $\quad$ Motifs, Oscar Wilde, Fairy tales, Oral Tradition, Motif Index

\section{Introduction}

Fairy tale is the subgenre of folktales (Swales, 1990). Fairy tales originated from the great oral folktales' tradition with the presence of magical elements. Fairy tales are considered a type of fictional work far away from truth (Zipes, 2001). Briggs (1971) calls fairy tales a part "of which charmed or paranormal are indispensable portion" (p. 133). Many scholars tried their best to read them again for their gay inclination (Summers, 1990; Schmidgall, 1994); for example the Christian factor has been traced (Quintus, 1991; Willoughby, 1993); many worked with the perspective of Jung (Snider, 2009) and the elements of politics, society and culture were also found from them (Killeen, 2007). Implications of this symbolic perspective have made them fit for the adults. However, it is losing its critical approach with perspective of genre. No sincere effort can be observed with regard to these tales' structure. One significant effort has been made by Monaghan (1974) who did the structural analysis of his two fairy tales but it lacked depth of quest.

Wilde was a famous writer of his age. After his marriage, he got issued his pioneer assortment of fairy tales The Happy Prince in 1888. No evidence has been provided to know why he at once was attracted to the writings of tales. Yet, "Wilde did not write them explicitly for children" (Zipes, 1999 p.135). His second tales' collection The House of Pomegranate was published in 1891. The picture of Dorian Gray was Wilde's most famous short novel published in the same year. Lady Windermere's Fan (1892), A Woman of No Importance (1893), An Ideal Husband (1895) and the importance of Being Earnest (1895) are his most famous plays.

Many scholars and writers of other countries offered a great deal of attention to this thought but in Pakistan no work has been done in this area, so this study is mainly done for this purpose. There had been a debate over the reason of writing his fairy tales. Some people said that he wrote them for his two sons as McCormack (1997) cited Wilde that it is the primary responsibility of every single father to pen fairy tales for his offspring, Wilde acknowledged, and countless of these tales, collected after the birth of his first two boys, these tales were narrated to them as Vyvyan recalls in one form or another. Wilde's tales are no doubt for children and should not been taken in serious manner, in the caption of Unsigned notice Athenaeum $1^{\text {st }}$ September 1888. His tales reflects the Victorian social inequalities. His tales has no happy endings. We cannot find any ideal world in his

ISP, Multan

** Department of English, Bahaudin Zakariya Uinversity,Layya Campus, Pakistan.

Email: zahoor_linguist@bzu.edu.pk

*** Department of English, Ghazi University Dera Ghazi Khan, Pakistan. Email: mahsan@gudgk.edu.pk 
fairy tales. The study was done to trace the motifs and their relationship with the Wilde's age in his selected tales and find the types of motifs in Wilde's fairy tales and how they depict his age.

\section{Literature Review}

The word fairy has been consequential term from Latin word 'fata', which is an optional of 'fatum' according to Warner (1995) fate is a 'divinity of destiny'. Through this origin the expression of French 'fee', fata, Italian and Spanish 'Hada' (p.14-15) has been derived. In the French romances 'fee' has been used for a "woman skilled in magic". They possess the supernatural powers and knowledge of occult. They used different type of herbs that keep them forever young; their secret knowledge of different herbs has helped them in this regard. Fata in Italian also carries the same connotations (Kready, 1916). Warner says (1995) "fairies share with sibyls knowledge of the future and the past, and in the stories which feature them, both types of figure foretell events to come, and give warnings" (p.15). For this reason fairies are associated with mysterious nature and supernatural. Good fairies are helpful, sympathetic and kind and bad fairies are cruel, malignant and deceitful. Warner also (1995) found the implication of 'obligation' and 'compelling' in the term fairy. Semantically, the connection of fay and fair, derived from the 'fegan' and 'feyen' meaning to suit, to agree and to meet the required purpose. This power has been controlled by the sprites. These pixies can be attached with their paranormal incantations, force people and exploit this excellence of power to harm and assist others (p.16). The term fairy is understood with the most popular senses that it is an illusion and magic. Fairyland is a territory where these types of creature live; and the individuals of this land (Kready, 1916). In the 14th century, the fourth sense was popular in Britain. With the appearance of Spencer's Faerie Queen in $16^{\text {th }}$ century, they came to known as the little creatures and became identified with beautiful maiden and elusive figures in human forms. Shakespeare's $A$ Midsummer Night's Dream (1916) also carries this similar connotation.

Oscar Fingal O'Flathertie Wills Wilde was born on 16 October 1854 in Dublin. His father was a well-known ENT physician who also earned name as a scholar and writer. His main interest was in the Irish archaeological lineage and traditional stories from his farmworker patients, frequently because of fee he poised fallacies, legends, and swearword and gems that might have been misplaced (Ellmann, 1987). The Irish Superstitions (1852) is an important work. In 1860s he received his Knighthood. Jane Francesca Wilde as his mother was an extraordinary bold woman. She also modified her name from Frances to Francesca. She was very inventive in naming her children. She added O 'Flahertie with the name of Oscar in consideration to William Wilde's connection with Galway. She also had great interest in the Irish folklore and nationalism as she wrote some patriotic verses on the place of women in society. He got his early education from Portorawhich a prestigious school. There he initially studied Greek. He also got Carpenter's prize for Greek scripture. He was very much influenced by his teacher Mahaffy was well-known for his allowance, generous expertise and freezing it (Pritchard, 2001) and the second one is R.Y Tyrrel was an additional astounding Hellenic researcher who had just been selected Professor of Latin at the age twenty-five (Pritchard, 2001 p.28). Wilde was completely dandy in school and he used to wear silk top hat to school. At Trinity College, his learning of aesthetics was perceptible. When he entered the Oxford, he earned good name. He had conventional attitude towards religion and authority. At Oxford, he was very much interested in the works of John Ruskin and Walter Peter. He established his reputation as a spokesman and conversationalist. He had been a very creative writer. He won coveted Newdigate Prize for his poem Ravenna (1845). He also wrote critical piece of work at the time of university. He was married to Constance Lloyd in 1884. He had two sons Cyril and Vyvyan from her. He has been an editor of Woman's World Magazine. His first collection of fairy tales was published in 1888. No evidence is present that shows the reason behind writing fairy tales. His second volume of fairy tales was published in 1891. Probably in 1890 his political essay 'The Soul of Man under Socialism' was published. His other plays which brought him good name was also published in these years entitled: Lady Windermere's Fan (1892), A Woman of no Importance (1893), An Ideal Husband (1895), The importance of Being Earnest (1895) and French version of Salome (1893).

He was alleged of homosexual relationship with Lord Alfred Douglas. Alfred's father Marquise of Queensbury's rude attitude made him aggressive. Wilde filed a case against Marquise for accusing him of homosexuality. But unfortunately, he was found guilty and was imprisoned for two years with hard labor. This period was proved most traumatic for him. On 21 November, 1895 he was transferred to Reading Goal from Wandsworth London Soul. This period was most humiliating for 
him. On that day he waited at the platform of Clampham Junction between 2:00 to 2:30. Crowed assembled there and laughed at him making fun of him. It broke him that he wrote in De Profundis (1897), "I wept every day at the same hour and for the same space of time (Ellmann, 1987, p. 465). During his stay in jail got the news of his wife's death. He wrote De Profundis (1897) for Alfred after feeling neglected by him. In 1897, he was released from prison. His attempt to re-establish his relationship with Alfred got failed. Later, he wrote 'The Ballad of Reading Goal' in 1898. This poem broke the previous records in market. This poem is called as 'Last Triumph' by Ellmann. He died at the age of forty six in a very cheap hotel named Hotel de Alsace. Wilde lived in such an age where his works did not get praise during his lifetime. People were more interested in his art of producing biographies. His open homosexuality led his personality to the interest of other people. It led the people to talk more about his captivated personality. The life of Oscar Wilde (1906) was first biography. It was produced by his friend Sherard. This biography shows his deep relationship with Wilde, "in which his spanies like devotion to Wilde's memory is at times an embarrassment" (Holland 1997, p.7). In 1914, another important biography came out with the title Lord Alfred Douglas' Oscar Wilde and me. Harris wrote another biography entitled 'Oscar Wilde: His Life and Confessions in 1916. This biography is filled with undue sensationalism. Holland argues that he portrayed Wilde's sexuality more profoundly as compared to others and also about his downfall because of Douglas. 'The Real Oscar Wilde' was produced in 1917; this biography describes the rude attitude of Alfred with Wilde. All these biographers of his times had been his close friends. Elements of subjectivity can be found in these biographies. Another biography in 1946 entitled Oscar Wilde: His works and Wit. It is considered the biography of great significance. Montgomery Hyde also wrote another biography 1977 entitled Oscar Wilde. This biography is mainly about Wilde's trails.

There are so many systems to classify fairy tales according to their tale types, motifs and functions. Thompson has introduced a classification of motifs, popularly which is known as Indics General Dei Motive (1937, Rev-1955-58). He divided motifs alphabetically for example A. stands for Mythological Motifs and B. for Animal Motifs. Following are the types of motifs introduced by Thompson in his classification 'Indics General Dei Motive (1937, Rev-1955-58).

\section{Table 1. Thompson Motif}

\begin{tabular}{clc}
\hline Sr. No. & \multicolumn{1}{c}{ Motif Type } & Frequency of motifs \\
\hline $\mathbf{1}$ & Mythological to Miscellaneous motifs (A) & A0-A2899 \\
$\mathbf{2}$ & Mythical Animal to Miscellaneous motifs (B) & B0-B899 \\
$\mathbf{3}$ & Taboo to Supernatural beings (C) & C0-C899 \\
$\mathbf{4}$ & Magic to Magic manifestation (D) & D0-D2199 \\
$\mathbf{5}$ & The dead to the soul (E) & E0-E799 \\
$\mathbf{6}$ & Marvel to Extraordinary journey (F) & F0-F1099 \\
$\mathbf{7}$ & Ogres to Other ogre motifs (G) & G0-G699 \\
$\mathbf{8}$ & Tests to other tests (H) & H0-H1599 \\
$\mathbf{9}$ & The wise and foolish to possession of wisdom (J) & J0-J2799 \\
$\mathbf{1 0}$ & Deception to false accusation (K) & K0-K2199 \\
$\mathbf{1 1}$ & Reversal of future (L) & L0-L99 \\
$\mathbf{1 2}$ & Ordaining the future (M) & M0-M99 \\
$\mathbf{1 3}$ & Society to society miscellaneous motifs (P) & P0-P799 \\
$\mathbf{1 4}$ & Rewards and punishment to punishment motifs (Q) & Q0-Q599 \\
$\mathbf{1 5}$ & Captives and fugitives to refuges and recapture (R) & R0-R399 \\
$\mathbf{1 6}$ & Unnatural cruelty to cruel persecutions (S) & S0-S499 \\
$\mathbf{1 7}$ & Sex to care for children (T) & T0-T699 \\
$\mathbf{1 8}$ & Nature of life to life miscellaneous motifs (U) & U0-U299 \\
$\mathbf{1 9}$ & Religion to religious motifs miscellaneous (V) & V0-V599 \\
$\mathbf{2 0}$ & Traits of character to traits of character miscellaneous (W) & W0-W299 \\
$\mathbf{2 1}$ & Humor to humor of lies and exaggeration (X) & X0-X1899 \\
$\mathbf{2 2}$ & Miscellaneous groups to heroes (Z) & Z0-Z299 \\
\hline
\end{tabular}

Motif Analysis of Oscar Wilde's Selected Fairy Tales

The researcher selected three tales for her thesis. They are as follows: The Happy Prince, The Selfish Giant and The Young King. 


\section{Motif Analysis of the Happy Prince}

The researcher chose 'The Happy Prince' from the Wilde's first collection of tales 'The Happy Prince and Other Tales' published in 1888. The Happy Prince is the very unique tale of Oscar Wilde. The researcher has found forty (40) motifs from this tale. The detail of the motif is given below:

Table 2: Motif Analysis of the Happy Prince

\begin{tabular}{|c|c|c|}
\hline Sr.\# & Motifs Nos. & Motif Name \\
\hline 1. & E68. & Apparently dead person revived when certain things happens \\
\hline 2. & E379. & Friendly return from the dead \\
\hline 3. & E545. & The dead speak \\
\hline 4. & E547. & The dead wail \\
\hline 5. & E340 & Return from dead to repay the obligations \\
\hline 6. & E539. & Other ghostly objects \\
\hline 7. & E770. & Vital objects \\
\hline 8. & E551. & Dead man sobs \\
\hline 9. & E649. & Reincarnation to objects \\
\hline 10. & E630. & Reincarnation in object \\
\hline 11. & E694. & Reincarnation as compensation \\
\hline 12 & E390 & Friendly return from the dead miscellaneous \\
\hline 13. & W10. & Kindness \\
\hline 14. & W28. & Self-sacrifice \\
\hline 15. & W31. & Obedience \\
\hline 16. & W33. & Heroism \\
\hline 17. & W32. & Bravery \\
\hline 18. & W11. & Generosity \\
\hline 19. & Z110. & Personification \\
\hline 20. & Z100. & Symbolism \\
\hline 21. & Z111. & Death personified \\
\hline 22. & Z133. & Poverty personified \\
\hline 23. & Z235. & Hero with extraordinary animal companion \\
\hline 24. & Z292. & Death of hero \\
\hline 25. & $\mathrm{P} 0$ & Royalty and nobility \\
\hline 26. & $\mathrm{P} 14.15 .1$ & Old, wise counselor of court \\
\hline 27. & $\mathrm{P} 14.15 .2$ & Court messenger \\
\hline 28. & P361.8 & Faithful servant undergoes torture for the sake of his master \\
\hline 29. & R0. & Captivity \\
\hline 30. & R100. & Rescues \\
\hline 31. & $\mathrm{R} 220$. & Flights \\
\hline 32. & R260. & Pursuits \\
\hline 33. & R310. & Refuges \\
\hline 34. & H900 & Imposed tasks \\
\hline 35. & H999 & Assignment and performance of tasks \\
\hline 36. & H960 & Tasks performed through cleverness and intelligence \\
\hline 37. & H1090 & Tasks required miraculous speed \\
\hline 38. & U60. & Wealth and poverty \\
\hline 39. & $\mathrm{U} 260$. & Passage of time \\
\hline 40. & S260. & Sacrifices \\
\hline
\end{tabular}

The fairy tale The Happy Prince comprises forty (40) motifs. There are eight types of motifs in this tale, such as motifs of The Dead (E), Traits of character (W), Miscellaneous Motifs (Z), Captives and Fugitives (R), Society (P), The Nature of life (U) and Unnatural Cruelty (S). All these motifs have been arranged according to their recurrence. The researcher found the following motifs of The Dead (E), they are as follows: Apparently dead person revived when certain things happen (E68), Friendly return from dead (E379), The dead speak (E545), The dead wail (E547), Return from the dead to repay the obligations (E340), Vital objects (E770), Dead man sobs (E551), Reincarnation to objects (E649), Reincarnation in objects (E630), Reincarnation as compensation (E694), Friendly return from the dead miscellaneous (E390) and Other ghostly objects (E539). Second type the traits of character (W), consists of six more motifs. They are as follows: kindness (W10), Self-sacrifice (W28), Obedience (W31), Heroism (W33), Bravery (W32) and Generosity (W11). Third type of motif is Miscellaneous Motifs consists of six more motifs. They are detailed as: Personification (Z110), 
Symbolism (Z100), Death personified (Z111); Poverty personified (Z133), Hero with extraordinary animal companion (Z235) and Death of hero (Z292). Fourth type of motif is 'Captives and Fugitives', which have five more motifs. They are described as follows: Captivity (R0), Rescues (R100), Flights (R220), Pursuits (R260) and Refuges (R310). Fifth type of motif is 'Society'. There are four more motifs. They are as follows: Royalty and nobility (P0), Old, wise counselor of court (P14.15.1), Court messenger (P14.15.2) and Faithful servant undergoes torture for the sake of his master (P361.8). Sixth type of motif is 'Tests', which consists of four more motifs. These motifs are as follows: Imposed tasks (H900), Assignment and performed through cleverness and intelligence (H960), Tasks required miraculous speed (H1090) and Assignment and performance of tasks (H999). Seventh type of motif is 'The Nature of life'. It consists of two more motifs which are as follows: Wealth and poverty (U60) and Passage of time (U260). Last type is "Unnatural Cruelty. It has only one motif in this tale which is 'Sacrifices (S260). This story "The Happy Prince" consists of maximum motifs of 'The dead (E)', 'Traits of Character (W)' and 'Miscellaneous Motifs (Z)'. Least occurred motifs are as following: Unnatural cruelty (S) and The Nature of life (U). There are also motifs which range between these two are as follows: Society $(\mathrm{P})$, Tests $(\mathrm{H})$ and Captives and fugitives $(\mathrm{R})$.

\section{The analysis of The Selfish Giant}

The researcher selected second tale also from the first collection of Wilde the Happy Prince and Other Tales published in 1888. She has found thirty-three (33) motifs from this tale. Their detail is given below:

\section{Table 3: The analysis of The Selfish Giant}

\begin{tabular}{|c|c|c|}
\hline Serial no. & Motif No. & Motif Name \\
\hline 1. & Q147.3 & Death by kiss from God \\
\hline 2. & Q36 & Reward of repentance \\
\hline 3. & Q36.1 & Confession of sins \\
\hline 4. & Q41 & Politeness rewarded \\
\hline 5. & Q56 & Love rewarded \\
\hline 6. & Q66 & Humility rewarded \\
\hline 7. & Q172.4.1 & Rooms in heaven are prepared for good man \\
\hline 8. & Q172.3 & Man admitted to heaven as reward for penance \\
\hline 9. & Q285 & Cruelty punished \\
\hline 10. & Q286 & Uncharitableness punished \\
\hline 11. & Q291 & Hard-heartedness punished \\
\hline 12. & Q313 & Bad temper punished \\
\hline 13. & Q556.11 & Curse for uncharitableness \\
\hline 14. & Q395 & Disrespect punished \\
\hline 15. & Q331 & Pride punished \\
\hline 16. & Q326 & Impudence punished \\
\hline 17. & W 155 & Hardness of heart \\
\hline 18. & W175 & Changeableness \\
\hline 19. & W185 & Violence of temper \\
\hline 20. & W187. & Insolence \\
\hline 21. & W188 & Contentiousness \\
\hline 22. & W196 & Lack of patience \\
\hline 23. & W215 & Extreme prudence \\
\hline 24. & $\mathrm{~L} 350$ & Mildness overcome violence \\
\hline 25. & L400 & Pride brought low \\
\hline 26. & L410 & Proud ruler humbled \\
\hline 27. & $\mathrm{~L} 473$ & Pride or wealth of man brought low by actions of god \\
\hline 28. & M423 & Curse removed when victim reformed \\
\hline 29. & M425 & Curse into blessing \\
\hline 30. & $\mathrm{U} 260$ & Passage of time \\
\hline 31. & $\mathrm{U} 262$ & Suffering healed by time \\
\hline 32. & V211.2 & Christ on earth \\
\hline 33. & V410 & Charity rewarded \\
\hline
\end{tabular}

The researcher found six types of motifs in this tale. They are motifs of Reward and punishment (Q), Traits of Character (W), Reversals of fortune (M), Ordaining of Future (L), The Nature of Life $(\mathrm{U})$ and Religion $(\mathrm{V})$. All these motifs are arranged according to their recurrence. First 
type of motif is Reward and punishment. The researcher found sixteen (16) more motifs. They are as follows: Death by kiss from God (Q147.3), Reward of repentance (Q36), Confession of sins (Q36.1), Politeness rewarded (Q41), Love rewarded (Q56), Humility rewarded (Q66), Rooms in heaven are prepared for good man (Q172.4.1), Man admitted to heaven as reward for penance (Q172.3), Cruelty punished (Q285), Uncharitableness punished (Q286), Hard heartedness punished (Q291), Bad-temper punished (Q313), Curse for uncharitableness (Q556.11), Disrespect punished (Q395), Pride punished (Q331) and Impudence punished (Q326). The second type of motif is The Traits of Character consists of seven more motifs which are detailed as: Hardness of heart (W155), Changeableness (W175), violence of temper (W185), insolence (W187), Contentiousness (W188), Lack of patience (W196) and Extreme prudence (W215). The third type of motif is The Reversals of fortune consists of four more motifs. They are detailed as: Mildness overcome violence (L350), Pride brought low (L400), Proud ruler humbled (L410) and Pride or wealth of man brought low by actions of god (L473). Fourth type of motif is Ordaining of Future. It comprises two more motifs. They are detailed as: Curse removed when victim reformed (M423) and Curse into blessing (M425). Fifth type of motif is The Nature of Life. It has also two more types. They are as follows: Passage of Time (U260) and Suffering healed by time (U262). The last type of motif is 'Religion' traced in this tale. It comprises two more motifs. They are detailed as: Christ on earth (V211.2) and Charity rewarded (V10). This tale has maximum motifs of 'Reward and punishment $(\mathrm{Q})$ and Traits of Character $(\mathrm{W})$ and least motifs are The Nature of Life (U) and Religion (V). The Reversals of Fortune (L) and Ordaining of Future (M) range between the motifs described before.

\section{Motif analysis of The Young King}

The researcher selected the third tale from the second volume of Wilde's fairy tale 'The House of Pomegranates' published in 1991. She found fifty-two (52) motifs from it. Their detail is given below:

Table 4: Motif analysis of The Young King

\begin{tabular}{|c|c|c|}
\hline Serial no. & Motif no & Motif Name \\
\hline 1. & $\mathrm{P} 0$ & Kings \\
\hline 2. & P30 & Princes \\
\hline 3. & P50 & Noblemen \\
\hline 4. & P90 & Royalty and Nobility- miscellaneous \\
\hline 5. & $\mathrm{P} 160$ & Beggars \\
\hline 6. & $\mathrm{P} 170$ & Slaves \\
\hline 7. & P360 & Master and servant \\
\hline 8. & $\mathrm{P} 410$ & Labors \\
\hline 9. & P200 & Family \\
\hline 10. & $\mathrm{P} 230$ & Parents and children \\
\hline 11. & P440 & Artisan \\
\hline 12. & P11 & Choice of king \\
\hline 13. & P12.9 & Nobility of character \\
\hline 14. & P12.14 & Modesty of king \\
\hline 15. & $\mathrm{P} 13.5$ & Crowning of king \\
\hline 16. & P13.9 & Royal perquisites \\
\hline 17. & P14.4 & King orders all gold brought to him \\
\hline 18. & $\mathrm{P} 41$ & Princess cannot married to someone of low caste \\
\hline 19. & $\mathrm{P} 231$ & Mother and son \\
\hline 20. & P291 & Grandfather \\
\hline 21. & P414 & Hunter \\
\hline 22. & P545.1 & Why weavers are the most unhappy \\
\hline 23. & $\mathrm{P} 445.2$ & Why weavers have patience \\
\hline 24. & P445 & Weaver \\
\hline 25 & $\mathrm{P} 14.15 .1$ & Court messenger \\
\hline 26. & P361.8 & Faithful servant undergoes torture for sake of his master \\
\hline 27. & $\mathrm{~T} 10$ & Falling in love \\
\hline 28. & $\mathrm{~T} 29$ & Falling in love-miscellaneous \\
\hline 29. & T50.2.1 & King unwilling to marry his daughter to man not her equal \\
\hline 30. & T56 & Means of attracting sweetheart \\
\hline 31. & T91 & Unequals in love \\
\hline 32. & T90 & Love \\
\hline 33. & T91.5 & Rich and poor in love \\
\hline
\end{tabular}




\begin{tabular}{lll} 
34. & T 91.5 .1 & Rich girl in love with poor boy \\
35. & T 91.6 & Noble and lowly in love \\
36. & T 91.6 .4 & Princes falls in low with lowly boy \\
37. & T 91.7 & Unequals in love \\
38. & T 100 & Marriage \\
39. & T 121 & Unequals marriage \\
40. & T 121.3 .1 & Princess marries lowly man \\
41. & T 131.1 .3 & Marriage against will of parents \\
42. & T 589 & Childbirth- miscellaneous motif \\
43. & W 28 & Self-sacrifice \\
44. & W 33 & Heroism \\
45. & W 45 & Honor \\
46. & W 137 & Curiosity \\
47. & U 60 & Wealth and poverty \\
48. & U 260 & Passage of time \\
49. & H 999 & Assignment and performance of tasks \\
50. & H 900 & Imposed tasks \\
51. & S 260 & Sacrifices \\
52. & R 260 & Pursuits \\
\hline
\end{tabular}

The researcher found seven types of motifs in this tale The Young King. They are motifs of Society (P), Sex (T), Traits of Character (W), The Nature of Life (U), Tests (H), Unnatural Cruelty (S) and Captives and Fugitives (R). All these motifs are arranged according to their recurrence. From the first type of motif 'Society', the researcher found twenty-six (26) more motifs. They are as follows: Kings (P0), Princes (P30), Noblemen (P50), Royalty and nobility- miscellaneous (P90), Beggars (P160), Slaves (P170), Master and servant (360), Labors (P410), Family (P200), Parents and children (P230), Artisan (P440), Choice of king (P11), Nobility of character (P12.9), Modesty of king (P12.14), Crowning of king (P13.5), Royal perquisites (P13.9), King orders all gold brought to him (P14.4), Princes cannot married to someone of low caste (P41), Mother and son (P231), Grandfather (P291), Hunter (P414), Why weaver are the most unhappy (P545.1), Why weaver have patience (P445.2), Weaver (P445), Court messenger (P14.15.1) and Faithful servant undergoes torture for the sake of master (P361.8). Second type of motif is Sex. It has sixteen (16) more motifs. They are detailed as: Falling in love (T10), Falling in love-miscellaneous (T29), King unwilling to marry his daughter not her equal (T50.2.1), Means of attracting sweetheart (T56), Unequals in love (T91), Love (T90), Rich and poor in love (T91.5), Rich girl in love with poor boy (T91.5.1), Noble and lowly in love (T91.6), Princes falls in love with lowly boy (T191.6.4), Unequals in love (T91.7), Marriage (T100), Unequals marriage (T121), Princes marries lowly man (T121.3.1), Marriage against will of parents (T131.1.3), and Childbirth-miscellaneous motif (T589). Third type of motif is Traits of character. There are four more motifs. They are as follows: Self-sacrifice (W28), Heroism (W33), Honor (W45) and Curiosity (W137). Fourth type of motif is The Nature of life; the researcher found two more motifs in this tale. They are as detailed: Wealth and poverty (U60) and Passage of time (W260). Fifth type of motif is Tests. There are two more motifs used in this tale. They are as follows: Assignment and performance of tasks (H999) and Imposed tasks (H900). Sixth type of motif is Unnatural cruelty. It has one more motif which is Sacrifices (S260). Last type of motif is Captives and fugitives. It has also one more motif. It is Pursuits (R260). The researcher has found maximum motifs of Society (P) and Sex (T) in this tale. 'The nature of life (U)' and 'Tests $(\mathrm{H})$ ' are the least used motifs in this tale. 'Traits of character (W) and 'Captives and fugitives (R) are the motifs which range between the motifs mentioned before.

\section{Discussion}

There are so many systems to classify fairy tales according to their tale types and motifs. Classification of motifs is given by Thompson (1885), he has divided motifs alphabetically. The Researcher found 125 motifs from these selected fairy tales. The first tale The Happy Prince consists of 40 motifs, The Selfish Giant 33 motifs and The Young King 52 motifs respectively. Following are the thirteen types of motifs found from all these tales: The Dead (E) 12, Traits of Character (W) 17, Miscellaneous Motifs (Z) 6, Captives and fugitives ( R) 6, Society (P) 30, Tests (H) 6, The Nature of Life (U) 5, Unnatural cruelty (S) 2, Reward and Punishment (Q) 16, Reversals of Fortune (M) 4, Ordaining of Future (L) 2, Religion (V) 2, Sex (T) 26. Six types of motifs are found in every tale are 
detailed as: Traits of character, Captives and Fugitives, Society, The Nature of Life, Unnatural Cruelty and Tests. Least used motifs are Unnatural cruelty, Ordaining of Future, Religion and Reversal of fortune.

Society is the motif which is most recurring in the fairy tale The Happy Prince: "High above the city, on a tall column, stood the statue of the Happy Prince" (p.560). The second most occurring motif is Sex, from the Selfish Giant, its examples can be traced out as: "And he kissed the Happy prince on his lips, and fell down dead at his feet" (p.565). Traits of the Character are another most recurring motifs, which is were found in all these selected tales. Its example can be seen from The Happy Prince as: "Pluck out one of them and take it to him" (p.563). In The Selfish Giant's the trait of selfishness in the Giant is explained in the following words as: "anyone can understand that, and I will allow nobody to play in it but myself," (p.570). In The Young King heroism can be found in this line as: "But no man dared look upon his face, for it was like the face of an angel" (p.515). Next motif is Reversals of fortune; in The Selfish Giant we clearly find the instances of the reversal of fortune. Last most found motif is the Dead, from The Happy Prince; this motif is used in this tale in great number. The prince was dead but after his death he came to realize the mistakes he has done during the days of his life, "And now that I am dead they have set me up here so high that I can see all the ugliness and all the misery of my city, and though my heart is made of lead yet I cannot chose but weep" (p.561).

The most recurring motifs in The Happy Prince are the dead, traits of character and the least used motifs are unnatural cruelty and captives and fugitives. In The Selfish Giant reward and punishment and trait of characters are the most occurred motifs and the least ones are the nature of life and religion. In The Young King motif of society and sex is most recurring ones, in the society motif there are 26 more motifs and the least used are traits of character and captives and fugitives. In the first tale The Happy Prince, the researcher has found eight types of motifs which have sub-division as well. They are motifs of The Dead (E), Traits of character (W), Miscellaneous Group of Motifs (Z), Captives and Fugitives (R), Society (P), The Nature of life (U) and Unnatural Cruelty (S). Third type of motif 'miscellaneous motif' is also found in the tale in the form of symbolism, poverty and hero is also interaction with his extraordinary companion. Fourth type of motif is seen in the form of captivity, flight and refuges "all the long day he flew, and at night he arrived at the city" (p.561). Fifth type of motif is society, Sixth type is tests, this type of motif is very prominent in this tale, and swallow performed very tough tasks for his master's love "it is very cool here," he said, "but I will stay with you for one night, and be your messenger" (p.562). Seventh type is about the change of time and poverty; we can see the change of heart of prince with the passage of time. The last type is unnatural cruelty which is found in the sacrifices of prince for his people. In this tale, more motifs of the dead, traits of characters and miscellaneous motifs are found.

The Selfish Giant has six types of motifs; they are motifs of 'Reward and punishment (Q)', 'Traits of Character (W)', 'Reversals of fortune (M)', 'Ordaining of Future (M)', 'The Nature of Life (U)' and Religion (V). First type of motif can be seen in the punishment of Giant's for committing a mistake, "he cried in a very gruff voice, and the children ran away" (p.570), and later he was rewarded for becoming good to the children. The second type of motif is traits of character, the characterization of Giant, his temper and violence "anyone can understand that, and I will allow nobody to play in it but myself" (p.570). Third type of motif is realized when due to his bad temper, winter stayed at his garden for long time as punishment. Fourth type of motif is about blessings which came to Giant after the transformation of his nature "You let me play once in your garden, to-day you shall come with me to my garden which is Paradise" (p.572). Fifth type of motif can be realized with the passage of time, the sufferings of Giant's turned into blessing. Last motif is found with the arrival of Christ in the form of little boy. This tale had more motifs in number of reward and punishment and traits of character. In The Young King, researcher found seven types of motifs with further division. They are motifs of 'Society (P)', 'Sex (T)', 'Traits of Character (W)', The Nature of Life (U)', 'Tests $(\mathrm{H})$ ', 'Unnatural Cruelty (S)' and 'Captives and Fugitives (R). The societal motifs are found in this tale in great number as compared to previous two tales, royalty, nobility, beggars, master, labors, family and so many other motifs related to society. The second type of motif love, he story has been started with the theme of love marriage of the princess "a secret marriage with one much beneath her in station" (p.507). Third type of motif is also seen in the character of protagonist, when he sacrificed everything for poor people and proved him as a hero. Fourth type of motif is felt with transformation of king's heart. Fifth type of motif can be found, when king ordered his servants to bring him precious 
stones at the cost of their lives. Next type of motif is about king's sacrifices; last one motif is seen in the character of king, who done great sacrifices in order to get the love of his people "will they not know me for a king if I have not a king's raiment" (p.513).

\section{Conclusion}

Through this study an effort has been made to truly investigate the fairy tales of Wilde, this piece of writing is not about his eccentricity in writing or about gay inclinations. In his tales, he remained close to the conventions of writing fairy tales and at the same time, he asserted himself as well. This analysis established these tales within genre. We cannot consider it only writing for children; they are for the people of all ages. He explained all the conventional themes of kindness and love. These tales can be taken as genuine piece of writing on many grounds. Finally, we can say that his tales are in many ways multilayered. A great effort has been done by Wilde in this area of writing.

\section{References}

Briggs, K. (1971). A Dictionary of British Folktales in the English Language. London: Routledge \& Kegan Paul.

Hawthorne, H. (1850). 'The Scarlet Letter. United States: Ticknor

Hardy, T. (1878). 'The Return of the Native'. United Kingdom: The magazine of Fashion and Amusement

Kready, F.L. (1916). A Study of Fairy Tales. Boston: The Riverside Press.

Killeen, J. (2007). The Fairy Tales of Oscar Wilde. U.S.A: Routledge.

Kready, F.L. (1916). Astudy Of Fairy Tales. Boston: Houghton Mifflin Company, the Riverside Press. Retrieved from: www.Sacred-texts.com.

Maeterlinck, M. (2011). L'Artmoderene. United Kingdom: Cambridge Scholars Publishing United Kingdo.

Mccormack, J. (1997). 'Wilde's Fictions'. In Raby, P. The Cambridge Companion to Oscar Wilde (ed.) (1997), pp. 96-117.

Monaghan, D. (1974). 'The Literary Fairy Tale: A Study of Oscar Wilde'. The Canadian Review of Comparative Literature, 1(2), 156-166.

Quintus, A. J. (1991). 'Christ, Christianity, and Oscar Wilde'. Texas Studies in Literature and Language, 33(4), 514-527.

Schmidgall, G. (1994). The Stranger Wilde: Interpreting Oscar. New York: Dutton.

Shakespeare, W. (2016). 'A Midsummer Night Dream'. United Kingdom: Macmillan Collector's Library.

Snider, C. (2009). "On the Loom of Sorrow". Eros and Logos in Oscar Wilde Fairy Tales. Retrieved from: www.csulb.edu/ csnider/wilde.fairy.tales/html (25.7.2019)

Summers, C.J. (1990). Gay Fictions: Wilde to Stonewall. Studies in a Male Homosexual Literary Tradition. New York: Continuum.

Swales, J. (1990). Genre Analysis. Cambridge: Cambridge University Press.

Thompson, S. (1955-1958).The Motif-Index of Folk Literature.[...] Revised and enlarged edition. Bloomington: Indiana University Press.

Warner, M. (1995). From the Beast to the Blonde: On Fairy Tales and Their Tellers. London: Vintage.

Willoughby, G. (1993). Art and Christhood: The Aesthetics of Oscar Wilde. New York: Fairleigh Dickinson.

Zipes, J. (ed.). (1999) The Great Fairy tales Tradition: From STRAPAROLA and BASILE to the BROTHERS GRIMM. A Norton Critical Edition. New York:

Zipes, J. (1987). Victorian Fairy Tales: the revolt of the fairies and elves. New York: Routledge.

Zipes, J. (1999a). When Dreams Come True. Routledge: London.

Zipes, J. (ed.) (2001b). 'Introduction'.(xiv-xiv) In Zipes.(ed.) 2001.

Zipes, J. (ed.) (2001c). "Cross-Cultural Connections and the Contamination of the Classical Fairy Tale”. (845-868) In Zipes. (ed.) 2001 